\title{
Highly Sensitive and Selective Ethanol Sensors Using Magnesium doped Indium Oxide Hollow Spheres
}

\author{
Young-Moo Jo*, Chul-Soon Lee*, Rui Wang*, Joon-Shik Park**, and Jong-Heun Lee*, \\ *Department of Materials Science and Engineering, Korea University, Seoul 02841, Korea \\ ** Smart Sensor Research Center, Korea Electronic Technology Institute, Seongnam 13509, Korea
}

(Received May 13, 2017; Revised June 4, 2017; Accepted June 5, 2017)

\begin{abstract}
Pure $\mathrm{In}_{2} \mathrm{O}_{3}, 0.5$ and $1.0 \mathrm{wt} \% \mathrm{Mg}$ doped $\operatorname{In}_{2} \mathrm{O}_{3}$ hollow spheres were synthesized by ultrasonic spray pyrolysis of a solution containing In-, Mg-nitrate and sucrose and their gas sensing characteristics to $5 \mathrm{ppm} \mathrm{C}_{2} \mathrm{H}_{5} \mathrm{OH}$, $p$-xylene, toluene, and $\mathrm{HCHO}$ were measured at 250,300 and $350^{\circ} \mathrm{C}$. Although the addition of $\mathrm{Mg}$ decreases the specific surface area and the volume of meso-pores, the gas response (resistance ratio) of the $0.5 \mathrm{wt} \% \mathrm{Mg}$ doped $\mathrm{In}_{2} \mathrm{O}_{3}$ hollow spheres to 5 ppm $\mathrm{C}_{2} \mathrm{H}_{5} \mathrm{OH}$ at $350^{\circ} \mathrm{C}(69.4)$ was significantly higher than that of the pure $\operatorname{In}_{2} \mathrm{O}_{3}$ hollow spheres (24.4). In addition, the $\mathrm{Mg}$ doped $\operatorname{In}_{2} \mathrm{O}_{3}$ hollow spheres showed the highest selectivity to $\mathrm{C}_{2} \mathrm{H}_{5} \mathrm{OH}$. This was attributed to the dehydrogenation of $\mathrm{C}_{2} \mathrm{H}_{5} \mathrm{OH}$ assisted by basic $\mathrm{MgO}$ into reactive $\mathrm{CH}_{3} \mathrm{CHO}$ and $\mathrm{H}_{2}$.
\end{abstract}

Key words : Sensors, Electrical properties, Gas sensor, Indium oxide, Magnesium

\section{Introduction}

$\mathrm{G}$ as sensors are used extensively in many fields, includTing industrial safety, environment, and life and health applications. Oxide semiconductor-type gas sensors exhibit chemiresistive variation by the reaction between analyte gas and the oxygen molecules adsorbed to the sensing material surface. Main advantages of oxide semiconductor-type gas sensors are simple working principle, high sensitivity, facile miniaturization, and rapid gas response. ${ }^{1)}$

Most gas sensing materials that have been studied to date are n-type oxide semiconductors, including $\mathrm{SnO}_{2},{ }^{2,3)} \mathrm{ZnO}$, ${ }^{4,5)}$ $\mathrm{TiO}_{2}{ }^{6)}$ and $\left.\mathrm{In}_{2} \mathrm{O}_{3} .{ }^{7}\right)$ Among these, $\mathrm{In}_{2} \mathrm{O}_{3}$ has drawn attention as a material suitable for wearable and flexible devices because of its transparency and high conductivity. ${ }^{8)}$ In addition, many studies have been conducted using $\operatorname{In}_{2} \mathrm{O}_{3}$ nanoparticles in gas sensors, have a high sensitivity to reducing gases. The resistance of n-type oxide semiconductors is increased when oxygen is adsorbed to the surface of the particle, which is then negatively charged, because an electron depletion layer is formed near the particle surface. If reducing gases, such as $\mathrm{C}_{2} \mathrm{H}_{5} \mathrm{OH}, p$-xylene, toluene, and $\mathrm{HCHO}$, react with the oxygen adsorbed with negative charge, the electrons are transported to the inside of the n-type oxide semiconductors, resulting in a decrease in resistance, due to the thinning of the electron depletion layer. ${ }^{9)}$ Liang et al. improved the hydrogen sulfide sensing characteristics of a sensor by using indium oxide containing a copper oxide as

${ }^{\dagger}$ Corresponding author: Jong-Heun Lee

E-mail : jongheun@korea.ac.kr

Tel : +82-2-3290-3282 Fax : +82-2-928-3584 the gas sensing substance, ${ }^{10)}$ and Rai et al. significantly increased gas sensing characteristics by employing a Pddoped indium oxide. ${ }^{11}$

Oxide-based nanostructures which have a large specific surface area, such as hollow structures, ${ }^{12)}$ nanowires, ${ }^{4,13)}$ nanofibers, ${ }^{3,5,10)}$ hierarchical structures, ${ }^{14)}$ and porous nanostructures, ${ }^{15)}$ can also improve gas sensitivity, and have been extensively applied to gas sensors. The methods for synthesizing oxide nanostructures include the hydrothermal method, ${ }^{7,14}$ electrospinning, ${ }^{3,5,10)}$ and ultrasonic spray pyrolysis. ${ }^{12,15,16,17)}$ In ultrasonic spray pyrolysis, microdroplets generated by ultrasonic transduction are thermally pyrolyzed in a high-temperature electric furnace to synthesize porous hollow nanostructures. This method is easy and simple, and enables mass production and facile control of composition and doping. ${ }^{17)}$

In the present study, pure and Mg-doped $\operatorname{In}_{2} \mathrm{O}_{3}$ spheres were prepared using ultrasonic spray pyrolysis to investigate the effect of $\mathrm{Mg}$ doping on the gas sensing characteristics of $\mathrm{In}_{2} \mathrm{O}_{3}$ spheres. The result showed that $\mathrm{Mg}$ doping at specific concentrations significantly enhanced the response and selectivity for ethanol. The gas sensing mechanism was also investigated in relation to $\mathrm{Mg}$ additive.

\section{Experimental Procedure}

\subsection{Synthesis of $\mathrm{In}_{2} \mathrm{O}_{3}$}

A spray solution for the synthesis of $\operatorname{In}_{2} \mathrm{O}_{3}$ hollow nanoparticles was prepared using the following procedures. 7.52 $\mathrm{g}$ of $\mathrm{In}\left(\mathrm{NO}_{3}\right)_{3} \cdot \mathrm{xH}_{2} \mathrm{O}(99.99 \%$, Sigma-Aldrich Co., Ltd., USA) and $17.11 \mathrm{~g}$ of sucrose (99.5\%, Sigma-Aldrich Co., Ltd., USA) were added to $500 \mathrm{ml}$ of distilled water. The resulting 
mixture solution was stirred for $2 \mathrm{~h}$. Spray solutions for the synthesis of $\mathrm{In}_{2} \mathrm{O}_{3}$ hollow nanoparticles doped with $0.5 \mathrm{wt} \%$ and $1.0 \mathrm{wt} \% \mathrm{Mg}$ were also prepared by the same method. 0.15 and $0.29 \mathrm{~g} \mathrm{Mg}\left(\mathrm{NO}_{3}\right)_{2} \cdot 6 \mathrm{H}_{2} \mathrm{O}(99.99 \%$, Sigma-Aldrich Co., Ltd., USA) and 7.34 and $7.18 \mathrm{~g} \mathrm{In}\left(\mathrm{NO}_{3}\right)_{3} \cdot \mathrm{xH}_{2} \mathrm{O}$ were respectively added to $500 \mathrm{ml}$ of distilled solution with $17.11 \mathrm{~g}$ of sucrose, and the resulting solutions were stirred. The molar concentrations of the metal ions and sucrose were fixed at $0.05 \mathrm{M}$ and $0.1 \mathrm{M}$, respectively.

The mixed solutions were sprayed as small droplets by applying ultrasound (with a resonance frequency of 1.7 $\mathrm{MHz}$ ), and the sprayed droplets were transported by a carrier gas $\left(\mathrm{O}_{2}, 10 \mathrm{~L} / \mathrm{min}\right)$ to an electric furnace at $900^{\circ} \mathrm{C}$ where the droplets underwent pyrolysis. Synthesized precursor spherical particles were collected by using a bag filter and then thermally treated to obtain pure $\mathrm{In}_{2} \mathrm{O}_{3}$ and $0.5 \mathrm{wt} \%$ and $1 \mathrm{wt} \% \mathrm{Mg}$-doped $\mathrm{In}_{2} \mathrm{O}_{3}$ hollow nanoparticles (referred to as $\mathrm{In}_{2} \mathrm{O}_{3}, 0.5 \mathrm{Mg}-\mathrm{In}_{2} \mathrm{O}_{3}$, and $1.0 \mathrm{Mg}-\mathrm{In}_{2} \mathrm{O}_{3}$, respectively).

\subsection{Sample Analysis}

A field emission-scanning electron microscope (FE-SEM, S-4300, Hitachi) and a transmission electron microscope (TEM, Talos F200X, FEI) were used to analyze the shapes of the synthesized powders. An X-ray diffractometer (Rigaku D/MAX-2500V/PC, CuK $\alpha$ line = $1.5418 \AA$ ) was used to analyze the crystal structure of the substances. BrunauerEmmett-Teller method (BET, Tristar 3000, Micrometrics) was employed to verify the specific area and pore distribution of the particles.

\subsection{Fabrication and Measurement of Sensor Device}

The synthesized hollow nanoparticles were mixed with distilled water as a slurry, which was coated on an alumina substrate with two Au electrodes to fabricate a gas sensor device. The water residue in the coated sensor substance was eliminated and the sensor device was stabilized by performing thermal treatment at $500^{\circ} \mathrm{C}$ for $3 \mathrm{~h}$, using a heater formed at the backside of the substrate. Then, the gas responses were measured. The gas flow rate was fixed at $200 \mathrm{~cm}^{3} / \mathrm{min}$. The response was measured with four reducing gases, $\mathrm{C}_{2} \mathrm{H}_{5} \mathrm{OH}, p$-xylene, toluene, and $\mathrm{HCHO}$, at a concentration of $5 \mathrm{ppm}$ at temperatures of 250,300 , and $350^{\circ} \mathrm{C}$.

\section{Results and Discussion}

\subsection{Shape and Phase of Synthesized Powder}

The structures synthesized by ultrasonic spray pyrolysis were spherical regardless of the composition. The diameter of the spherical particles ranged from $500 \mathrm{~nm}$ to $1 \mu \mathrm{m}$, showing a relatively uniform size distribution (Figs. 1(a) to 1(f)). In the TEM images, the centers of the spherical $0.5 \mathrm{Mg}$ $\mathrm{In}_{2} \mathrm{O}_{3}$ and $1.0 \mathrm{Mg}-\mathrm{In}_{2} \mathrm{O}_{3}$ particles were found to be bright, indicating that the particles had a hollow structure (Figs. 2(a), 2(b), 2(f), and 2(g)). The thickness of the hollow structure shell layer was found to be about $16 \mathrm{~nm}$ (Figs. 2(b) and $2(\mathrm{~g}))$. The spherical indium salt-carbon composites were synthesized at the beginning stage of spray pyrolysis, and the hollow structure may have been formed when the carbon component was removed during the later stage of pyrolysis reaction. The energy dispersive spectrometer (EDS) analysis showed that the $\mathrm{Mg}$ components was uniformly doped in all the regions of the $\operatorname{In}_{2} \mathrm{O}_{3}$ particles, rather than being aggregated with each other (Figs. 2(c) to 2(e) and 2(h) to $2(\mathrm{j}))$.
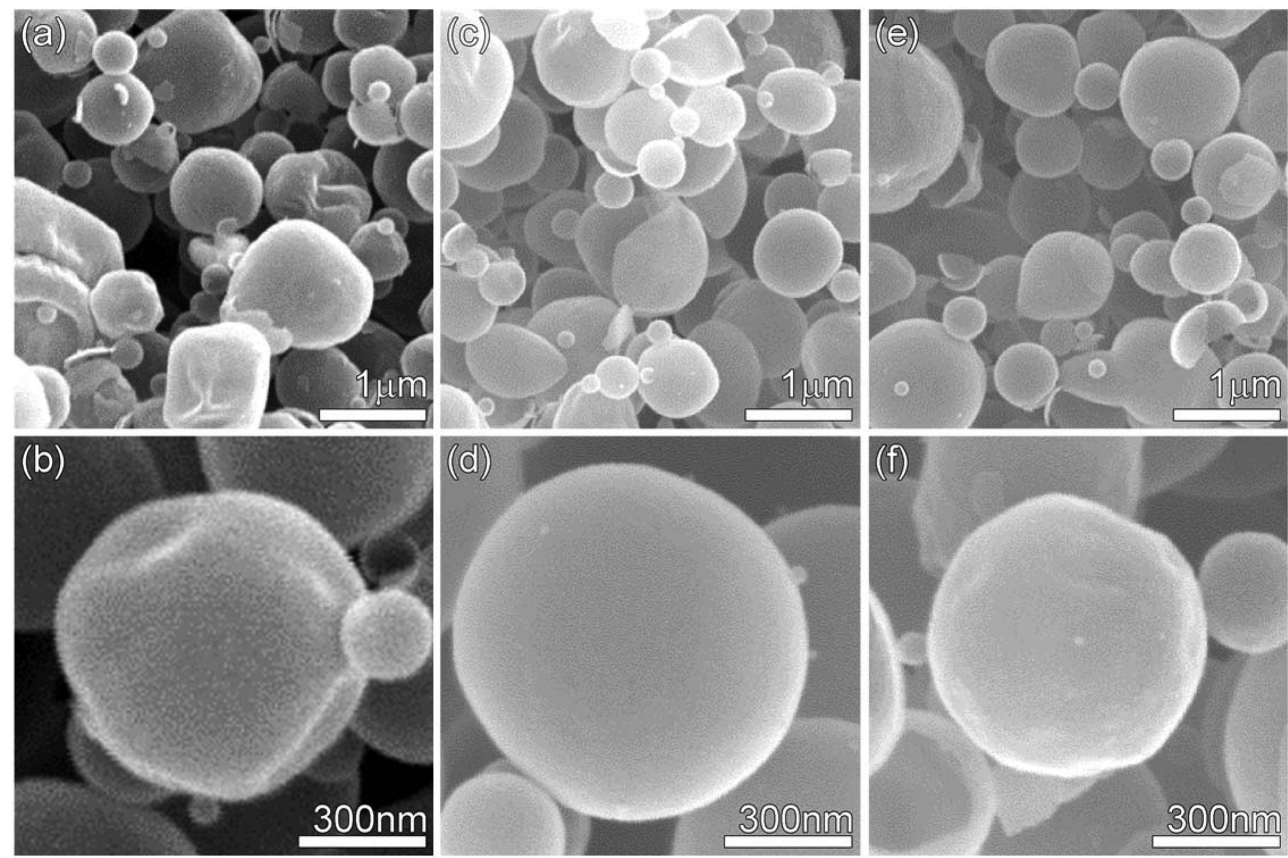

Fig. 1. SEM images of (a-b) pure- $\operatorname{In}_{2} \mathrm{O}_{3}$, (c-d) $0.5 \mathrm{Mg}-\mathrm{In}_{2} \mathrm{O}_{3}$ and (e-f) $1.0 \mathrm{Mg}-\mathrm{In}_{2} \mathrm{O}_{3}$ spheres prepared by spray pyrolysis reaction and subsequent heat treatment at $600^{\circ} \mathrm{C}$ for $3 \mathrm{~h}$. 

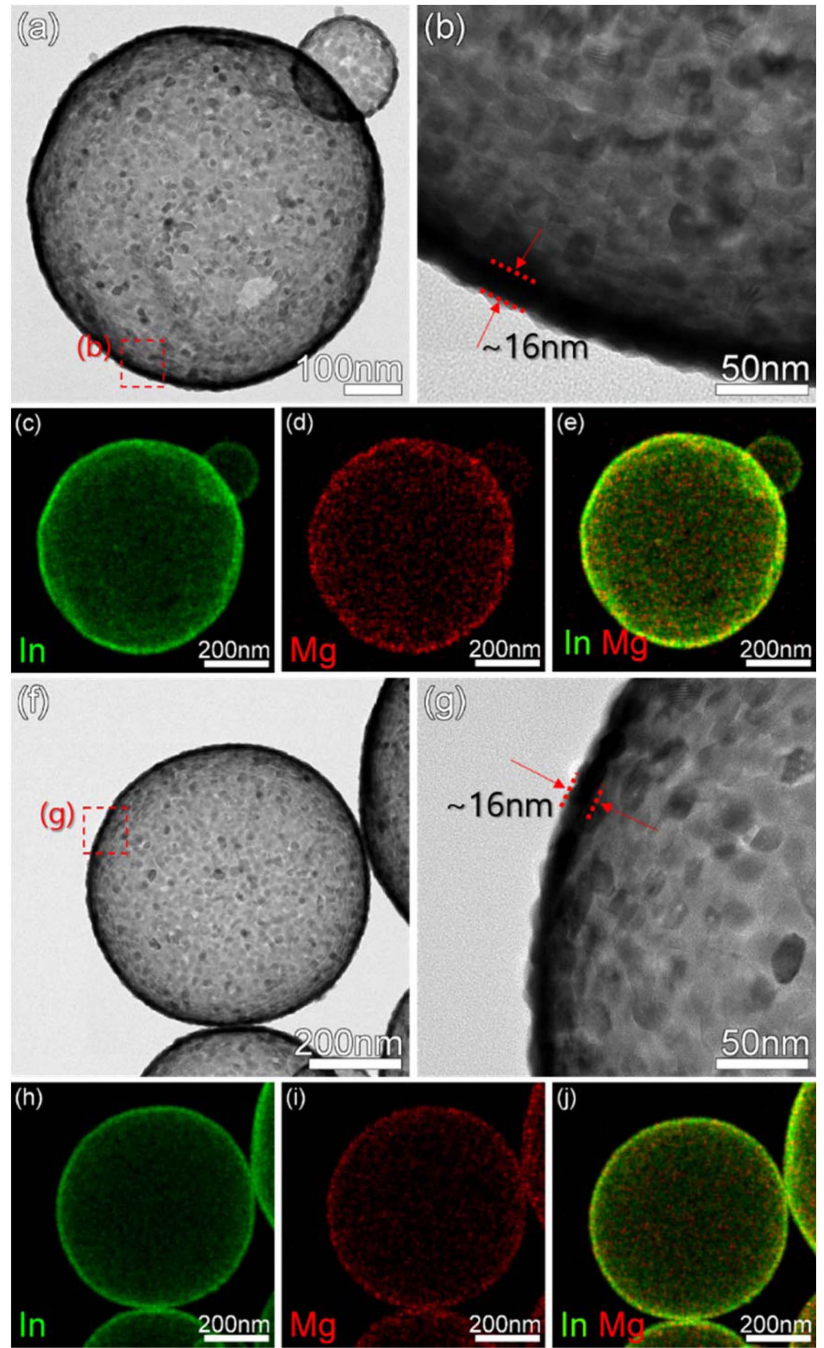

Fig. 2. TEM images and elemental mapping of (a-e) $0.5 \mathrm{Mg}$ $\mathrm{In}_{2} \mathrm{O}_{3}$ and (f-j) $1.0 \mathrm{Mg}-\mathrm{In}_{2} \mathrm{O}_{3}$ powders.

The X-ray diffraction analysis of the synthesized power showed $\mathrm{In}_{2} \mathrm{O}_{3}$ to have a body centered cubic structure (JCPDS \#06-0416), but no Mg oxide-related phase was found (JCPDS \#4-829) (Fig. 3). At the coordination number $(\mathrm{CN})$ of 6 , the ionic radius of $\mathrm{Mg}^{2+}$ is $0.86 \AA$, which is slightly smaller than that of $\operatorname{In}^{3+}(0.94 \AA)$ with the same $\mathrm{CN}$. The X-ray diffraction result suggests that $\mathrm{Mg}$ is doped into the $\mathrm{In}_{2} \mathrm{O}_{3}$ lattice, ${ }^{18)}$ or a small quantity of Mg-related secondary phase may have not been detected due to the detection limit of the X-ray diffractometer. The calculation based on the Scherrer's equation revealed that the primary particle diameter of the $\operatorname{In}_{2} \mathrm{O}_{3}$, $0.5 \mathrm{Mg}-\mathrm{In}_{2} \mathrm{O}_{3}$, and $1.0 \mathrm{Mg}-\operatorname{In}_{2} \mathrm{O}_{3}$ powders were $12.4,11.4$, and $13.5 \mathrm{~nm}$, respectively.

\subsection{Specific Surface Area and Pore Distribution}

The pore size and volume were measured by BET analysis (Fig. 4). The specific surface area of the $0.5 \mathrm{Mg}-\operatorname{In}_{2} \mathrm{O}_{3}$ and $1.0 \mathrm{Mg}-\mathrm{In}_{2} \mathrm{O}_{3}$ microparticles were $11.1 \mathrm{~m}^{3} / \mathrm{g}$ and $11.9 \mathrm{~m}^{3} / \mathrm{g}$, respectively, which is about half of the specific surface area

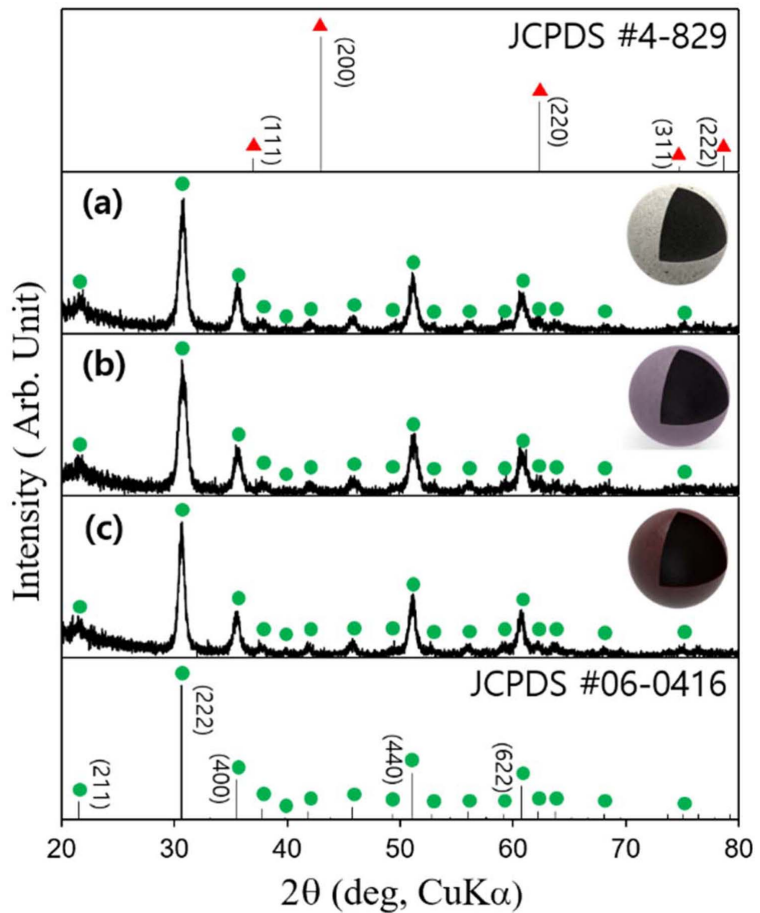

Fig. 3. X-ray diffraction patterns (XRD) of (a) pure-, (b) $0.5 \mathrm{Mg}$ $\mathrm{In}_{2} \mathrm{O}_{3}$ and (c) $1.0 \mathrm{Mg}-\mathrm{In}_{2} \mathrm{O}_{3}$ powders.

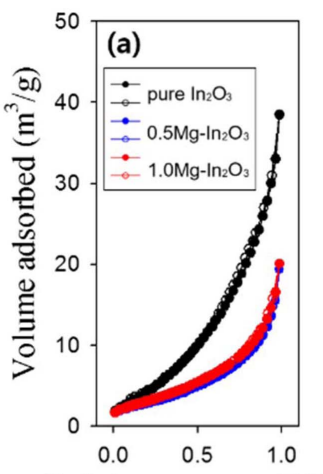

Relative pressure $\left(\mathrm{P} / \mathrm{P}_{0}\right)$

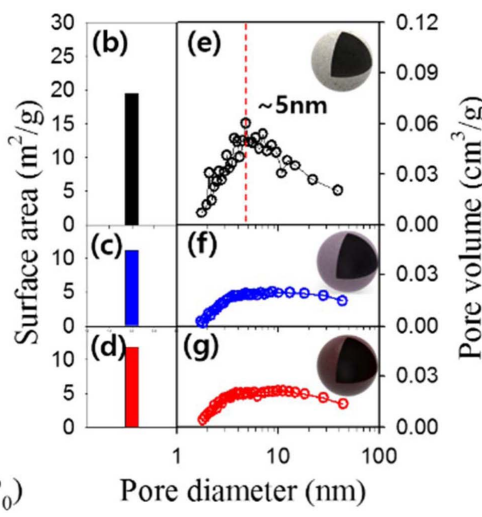

Fig. 4. (a) $\mathrm{N}_{2}$ adsorption/desorption isotherms of $\mathrm{In}_{2} \mathrm{O}_{3}$ (black), $0.5 \mathrm{Mg}-\mathrm{In}_{2} \mathrm{O}_{3}$ (blue) and $1.0 \mathrm{Mg}-\mathrm{In}_{2} \mathrm{O}_{3}$ (red). (b-g) Corresponding BET surface areas and pore-size distribution of $(b, e) \operatorname{In}_{2} \mathrm{O}_{3}$, (c, f) $0.5 \mathrm{Mg}-\operatorname{In}_{2} \mathrm{O}_{3}$ and $(\mathrm{d}, \mathrm{f}) 1.0 \mathrm{Mg}$ $\mathrm{In}_{2} \mathrm{O}_{3}$ powders.

of pure- $\mathrm{In}_{2} \mathrm{O}_{3}\left(19.5 \mathrm{~m}^{3} / \mathrm{g}\right.$ ) (Figs. 4(a) to $4(\mathrm{~d})$ ). The mesopores, with diameters of about $5 \mathrm{~nm}$, was decreased by the Mg doping (Figs. 4(e) to $4(\mathrm{~g})$ ), indicating that the specific surface area was decreased because the inserted $\mathrm{Mg}$ components blocked the pores.

\subsection{Evaluation of Gas Response}

The gas sensing characteristics were measured after stabilizing the sensing substances through thermal treatment for more than $1 \mathrm{~h}$ at 250,300 , and $350^{\circ} \mathrm{C}$. The gases undergoing the sensing test were $\mathrm{C}_{2} \mathrm{H}_{5} \mathrm{OH}$, xylene, toluene, and $\mathrm{HCHO}$ at $5 \mathrm{ppm}$. The gas response was defined as $R_{a} / R_{g}$ 


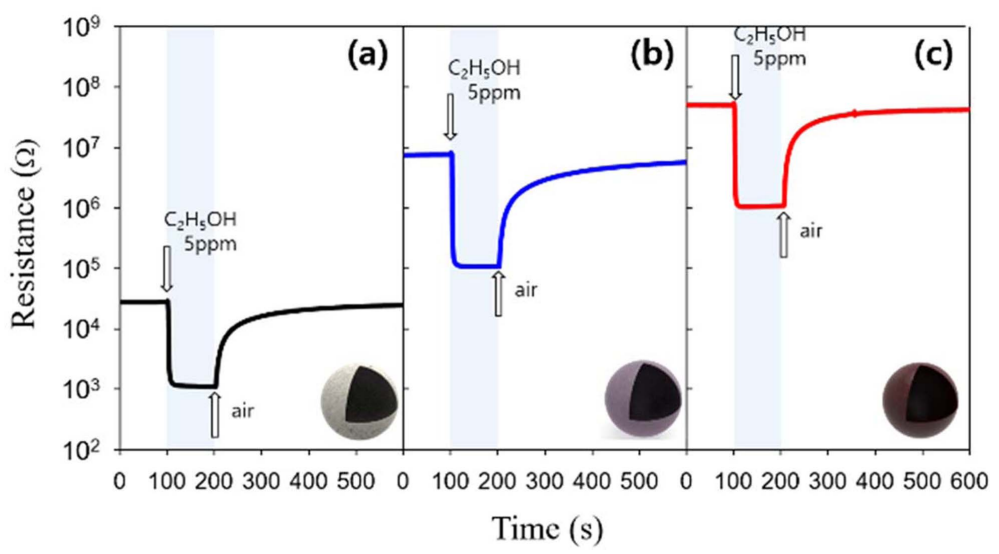

Fig. 5. Gas sensing transients of (a) $\mathrm{In}_{2} \mathrm{O}_{3}$, (b) $0.5 \mathrm{Mg}-\operatorname{In}_{2} \mathrm{O}_{3}$ and (c) $1.0 \mathrm{Mg}-\mathrm{In}_{2} \mathrm{O}_{3}$ hollow spheres to 5 ppm $\mathrm{C}_{2} \mathrm{H}_{5} \mathrm{OH}$ at $350^{\circ} \mathrm{C}$.

where $R_{a}$ denotes the resistance in the air and $R_{g}$ the resistance in the gas.

The responses to $5 \mathrm{ppm} \mathrm{C}_{2} \mathrm{H}_{5} \mathrm{OH}$ measured at $350^{\circ} \mathrm{C}$ with $\mathrm{In}_{2} \mathrm{O}_{3}, 0.5 \mathrm{Mg}-\mathrm{In}_{2} \mathrm{O}_{3}$, and $1.0 \mathrm{Mg}-\mathrm{In}_{2} \mathrm{O}_{3}$ were $24.4,69.4$, and 46.3, respectively (Figs. 5 and 6). This verified that the doping of $\mathrm{Mg}$ effectively increased the response of the $\mathrm{In}_{2} \mathrm{O}_{3}$ sensor. The sensor resistance in the air $\left(R_{a}\right)$ was increased from $27.3 \mathrm{~K} \Omega\left(\mathrm{In}_{2} \mathrm{O}_{3}\right)$ by 270 times and 1,840 times to $7.5 \mathrm{M} \Omega$ and $50.3 \mathrm{M} \Omega$ in the $0.5 \mathrm{Mg}-\mathrm{In}_{2} \mathrm{O}_{3}$ and $1.0 \mathrm{Mg}-\mathrm{In}_{2} \mathrm{O}_{3}$, respectively, depending on the quantity of doped $\mathrm{Mg}$. This indicated that the doping of $\mathrm{Mg}^{2+}$ played the role of an electron accepter to increase the overall resistance (Fig. 5). Assuming that a certain number of electrons are injected to the sensor through the gas sensing reaction, the response of $\mathrm{Mg}$-doped $\mathrm{In}_{2} \mathrm{O}_{3}$ will be higher because the electron concentration in the sensor is significantly lower. This may be a possible explanation of the increase of the gas response by $\mathrm{Mg}$ doping.

The gas response of individual powders was measured at all temperatures with all the test gases. The results showed

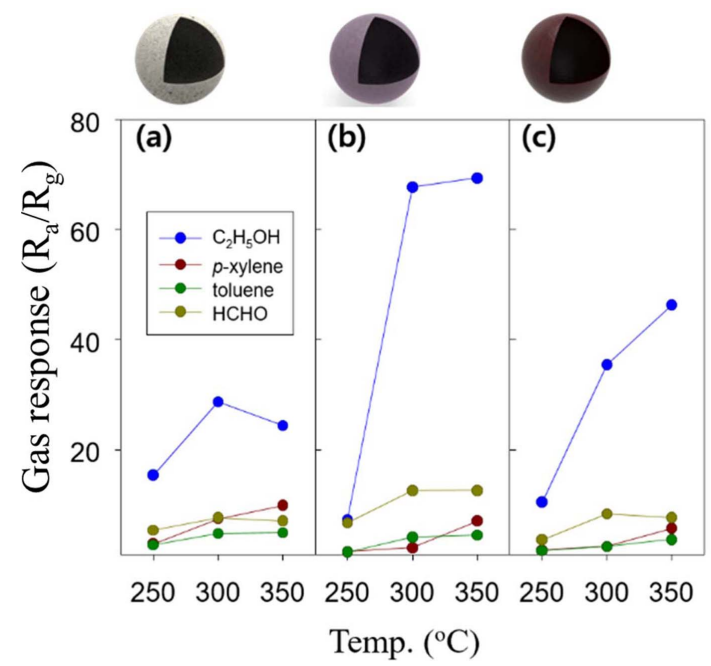

Fig. 6. Responses of (a) $\mathrm{In}_{2} \mathrm{O}_{3}$, (b) $0.5 \mathrm{Mg}-\mathrm{In}_{2} \mathrm{O}_{3}$ and (c) $1.0 \mathrm{Mg}$ $\mathrm{In}_{2} \mathrm{O}_{3}$ hollow spheres to $5 \mathrm{ppm}$ of analyte gases at 250,300 and $350^{\circ} \mathrm{C}\left(5 \mathrm{ppm} \mathrm{C}_{2} \mathrm{H}_{5} \mathrm{OH}, p\right.$-xylene, toluene, $\mathrm{HCHO}$ ). that the response was highest for the $\mathrm{C}_{2} \mathrm{H}_{5} \mathrm{OH}$ sensing with the pure $\mathrm{In}_{2} \mathrm{O}_{3}$ sensor, and the Mg-doped $\mathrm{In}_{2} \mathrm{O}_{3}$ sensors (Fig. $6)$. Generally, the response of the n-type oxide semiconductor gas sensors to $p$-xylene, toluene and $\mathrm{HCHO}$ was lower than that of $\mathrm{C}_{2} \mathrm{H}_{5} \mathrm{OH}$, because the gas reactivity with $\mathrm{C}_{2} \mathrm{H}_{5} \mathrm{OH}$ was highest, which is consistent with the result of the present study.

In comparison with pure $\operatorname{In}_{2} \mathrm{O}_{3}$, the addition of $\mathrm{Mg}$ greatly increased the response to $\mathrm{C}_{2} \mathrm{H}_{5} \mathrm{OH}$ but slightly increased or even decreased the response to $p$-xylene, toluene, and $\mathrm{HCHO}$, which are representative indoor hazardous gases. The selectivity to $\mathrm{C}_{2} \mathrm{H}_{5} \mathrm{OH}$ was calculated by dividing the response to $\mathrm{C}_{2} \mathrm{H}_{5} \mathrm{OH}$ with the response of other gases $\left(\mathrm{S}_{\mathrm{C} 2 \mathrm{H} 5 \mathrm{OH}} / \mathrm{S}_{\text {analyte gas }}\right)$ (Fig. 7). The $\mathrm{S}_{\mathrm{C} 2 \mathrm{H} 5 \mathrm{OH}} / \mathrm{S}_{\text {analyte gas }}$ value of the Mg-doped $\mathrm{In}_{2} \mathrm{O}_{3}$ sensors was significantly higher than that of the pure $\operatorname{In}_{2} \mathrm{O}_{3}$ sensor, indicating that the addition of $\mathrm{Mg}$ increased not only the response to $\mathrm{C}_{2} \mathrm{H}_{5} \mathrm{OH}$ but also the selectivity to $\mathrm{C}_{2} \mathrm{H}_{5} \mathrm{OH}$.

The increase in the response and the selectivity may be explained by the difference in reactivity between the $\mathrm{C}_{2} \mathrm{H}_{5} \mathrm{OH}$ and the acid-base surface. It has been reported that a dehy-

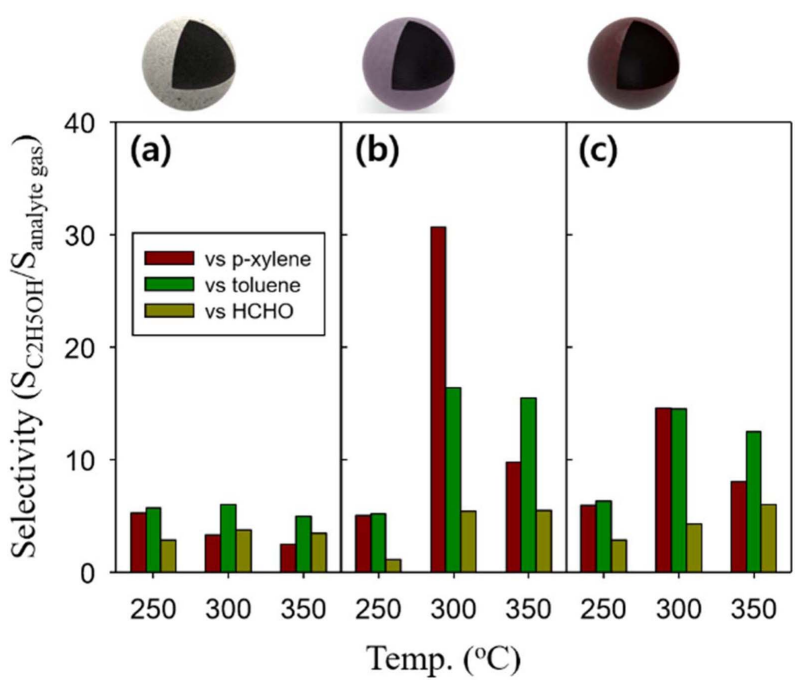

Fig. 7. $\mathrm{C}_{2} \mathrm{H}_{5} \mathrm{OH}$ selectivity $\left(\mathrm{S}_{\mathrm{C} 2 \mathrm{H} 5 \mathrm{OH}} / \mathrm{S}_{\text {analyte gas }}\right)$ of (a) $\mathrm{In}_{2} \mathrm{O}_{3}$, (b) $0.5 \mathrm{Mg}-\mathrm{In}_{2} \mathrm{O}_{3}$ and (c) $1.0 \mathrm{Mg}$ - $\operatorname{In}_{2} \mathrm{O}_{3}$ hollow spheres to 5 ppm of analyte gases at 250,300 and $350^{\circ} \mathrm{C} .{ }^{17}$ ) 
drating reaction occurs between $\mathrm{C}_{2} \mathrm{H}_{5} \mathrm{OH}$ and an acidic surface to result in the decomposition to $\mathrm{C}_{2} \mathrm{H}_{4}$ (g) and $\mathrm{H}_{2} \mathrm{O}(\mathrm{g})$, while a dehydrogenation reaction occurs between $\mathrm{C}_{2} \mathrm{H}_{5} \mathrm{OH}$ and a basic surface to result in the decomposition to $\mathrm{CH}_{3} \mathrm{CHO}(\mathrm{g})$ and $\mathrm{H}_{2}(\mathrm{~g}) .{ }^{13,19)}$ The $\mathrm{CH}_{3} \mathrm{CHO}(\mathrm{g})$ and $\mathrm{H}_{2}(\mathrm{~g})$ generated from the basic surface react with the negatively charged oxygen on the oxide surface better than the $\mathrm{C}_{2} \mathrm{H}_{4}(\mathrm{~g})$ and $\mathrm{H}_{2} \mathrm{O}$ (g) generated from the acidic surface, donating more electrons and showing a higher gas response. Since $\mathrm{Mg}$ is a representative alkaline substance, the $\mathrm{C}_{2} \mathrm{H}_{5} \mathrm{OH}$ dehydrogenation reaction enhanced by the $\mathrm{Mg}$ doping might have increased the response and selectivity to $\mathrm{C}_{2} \mathrm{H}_{5} \mathrm{OH}$.

\section{Conclusions}

Hollow spherical particles of pure- $\operatorname{In}_{2} \mathrm{O}_{3}$ and $0.5 \mathrm{wt} \%$ and 1.0 wt\% Mg-doped $\operatorname{In}_{2} \mathrm{O}_{3}$ were synthesized by ultrasonic spray pyrolysis, and their gas response was evaluated. The $\mathrm{C}_{2} \mathrm{H}_{5} \mathrm{OH}$ gas response was greatly improved by the addition of $\mathrm{Mg}$. Particularly in the sensor to which $0.5 \mathrm{wt} \% \mathrm{Mg}$ was added, the highest ethanol response was found at $350^{\circ} \mathrm{C}$, and the highest $p$-xylene selectivity was found at $300^{\circ} \mathrm{C}$. The $\mathrm{C}_{2} \mathrm{H}_{5} \mathrm{OH}$ gas response and selectivity were increased because alkaline $\mathrm{Mg}$ decomposed the $\mathrm{C}_{2} \mathrm{H}_{5} \mathrm{OH}$ into $\mathrm{CH}_{3} \mathrm{CHO}$ and $\mathrm{H}_{2}$, increasing the gas response, and because the addition of $\mathrm{Mg}$ decreased the background electron concentration of the sensor in air, making the resistance more sensitive to the gaseous reaction. The results of the present study show that Mg-doped oxides may be used to sense $\mathrm{C}_{2} \mathrm{H}_{5} \mathrm{OH}$ gas with high response and high selectivity.

\section{Acknowledgements}

This work is supported by the "S/W Converged Components Technology Development Program" (project No. 10043800) by KEIT and MOTIE in the Korea and Brain Pool Program (No. 161S-2-3-1544), through the Korean Federation of Science and Technology Societies (KOFST), funded by the Ministry of Science, ICT and Future Planning.

\section{REFERENCES}

1. N. Yamazoe, "Toward Innovations of Gas Sensor Technology," Sens. Actuator, B, 108 [1] 2-14 (2005).

2. B.-Y. Kim, J. S. Cho, J.-W. Yoon, C. W. Na, C.-S. Lee, J. H. Ahn, Y. C. Kang, and J.-H. Lee, "Extremely Sensitive Ethanol Sensor Using Pt-doped $\mathrm{SnO}_{2}$ Hollow Nanospheres Prepared by Kirkendall Diffusion,” Sens. Actuator, B, 234 353-60 (2016).

3. J. W. Jung, S. J. Park, I. B. Jeong, B.-Y. Kim, and J.-H. Lee, "Design of Highly Reliable Thick Film Gas Sensor Using $\mathrm{SnO}_{2}$ Nanofibers," J. Sensor Sci. \& Tech., 25 [4] 271-74 (2016).

4. H.-S. Woo, C.-H. Kwak, J.-H. Chung, and J.-H. Lee, "Highly Selective and Sensitive Xylene Sensors Using Ni-doped Branched ZnO Nanowire Networks," Sens. Actuator, B, 216 358-66 (2015).
5. B.-Y. Kim, J.-W. Yoon, C.-S. Lee, J.-S. Park, and J.-H. Lee, "Trimethylamine Sensing Characteristics of Molybdenum doped $\mathrm{ZnO}$ Hollow Nanofibers Prepared by Electrospinning," J. Sensor Sci. \& Tech., 24 [6] 419-22 (2015).

6. A. M. Ruiz, G. Sakai, A. Cornet, K. Shimanoe, and J. R. Morante, "Cr-doped $\mathrm{TiO}_{2}$ Gas Sensor for Exhaust $\mathrm{NO}_{2}$ Monitoring," Sens. Actuator, B, 93 [1] 509-18 (2003).

7. K.-I. Choi, H.-R. Kim, and J.-H. Lee, "Enhanced CO Sensing Characteristics of Hierarchical and Hollow $\operatorname{In}_{2} \mathrm{O}_{3}$ Microspheres," Sens. Actuator, B, 138 [2] 497-503 (2009).

8. J.-C. Park, S.-J. Kang, and Y.-S. Yoon, "Properties of IZTO Thin Films Deposited on PEN Substrates with Different Working Pressures," J. Korean Ceram. Soc., 52 [3] 224-27 (2015).

9. N. Yamazoe, G. Sakai, and K. Shimanoe, "Oxide Semiconductor Gas Sensors," Catal. Surv. Asia, 7 [1] 63-75 (2003).

10. X. Liang, T.-H. Kim, J.-W. Yoon, C.-H. Kwak, and J.-H. Lee, "Ultrasensitive and Ultraselective Detection of $\mathrm{H}_{2} \mathrm{~S}$ Using Electrospun CuO-loaded $\mathrm{In}_{2} \mathrm{O}_{3}$ Nanofiber Sensors Assisted by Pulse Heating," Sens. Actuator, B, 209 934-42 (2015).

11. P. Rai, J.-W. Yoon, C.-H. Kwak, and J.-H. Lee, "Role of Pd Nanoparticles on Gas Sensing Behaviour of $\mathrm{Pd} @ \mathrm{In}_{2} \mathrm{O}_{3}$ Yolk-Shell Nanoreactors," J. Mater. Chem. A, 4 [1] 264-69 (2016).

12. Y. H. Cho, X. Liang, Y. C. Kang, and J.-H. Lee, "Ultrasensitive Detection of Trimethylamine Using Rh-doped $\mathrm{SnO}_{2}$ Hollow Spheres Prepared by Ultrasonic Spray Pyrolysis," Sens. Actuator, B, 207 330-37 (2015).

13. C.-H. Kwak, H.-S. Woo, F. Abdel-Hady, A. A. Wazzan, and J.-H. Lee, "Vapor-Phase Growth of Urchin-like Mg-doped ZnO Nanowire Networks and their Application to Highly Sensitive and Selective Detection of Ethanol," Sens. Actuator, B, 223 527-34 (2016).

14. H.-J. Kim, J.-W. Yoon, K.-I. Choi, H. W. Jang, A. Umar, and J.-H. Lee, "Ultraselective and Sensitive Detection of Xylene and Toluene for Monitoring Indoor Air Pollution Using Cr-doped NiO Hierarchical Nanostructures," Nanoscale, 5 [15] 7066-73 (2013).

15. J.-W. Yoon, S. H. Choi, J.-S. Kim, H. W. Jang, Y. C. Kang, and J.-H. Lee, "Trimodally Porous $\mathrm{SnO}_{2}$ Nanospheres with Three-Dimensional Interconnec-tivity and Size Tunability: A One-Pot Synthetic Route and Potential Application as an Extremely Sensitive Ethanol Detector," NPG Asia Mater., 8 e244 (2016).

16. T.-H. Kim, J.-W. Yoon, and J.-H. Lee, "A Volatile Organic Compound Sensor Using Porous $\mathrm{Co}_{3} \mathrm{O}_{4}$ Spheres," J. Korean Ceram. Soc., 53 [2] 134-38 (2016).

17. G. L. Messing, S.-C. Zhang, and G. V. Jayanthi, "Ceramic Powder Synthesis by Spray Pyrolysis," J. Am. Ceram. Soc., 76 [11] 2707-26 (1993).

18. R. D. Shannon, "Revised Effective Ionic Radii and Systematic Studies of Interatomic Distances in Halides and Chalcogenides," Acta Cryst., A32 [5] 751-67 (1976).

19. T. Jinkawa, G. Sakai, J. Tamaki, N. Miura, and N. Yamazoe, "Relationship between Ethanol Gas Sensitivity and Surface Catalytic Property of Tin Oxide Sensors Modified with Acidic or Basic Oxides," J. Mol. Catal. A: Chem., 155 193-200 (2000). 